\title{
MARKÓ VERONIKA
}

\section{Szabó Dezső első és utolsó könyvtára}

Szabó Dezső, a szenvedélyes könyvgyüjtő élete során többször vált meg - hol kényszerből, hol saját akaratából - addig gyüjtött könyvtárától. Közismert, hogy halála után könyvei az Eötvös Collegium könyvtárába (ma MTA Bölcsészettudományi Kutatóközpont Irodalomtudományi Intézet Eötvös Könyvtár) kerültek, ${ }^{1}$ az azonban feledésbe merült, hogy első gyüjteményét is itt őrizzük már csaknem száz éve.

Az elsö

Szabó Dezső 1900-tól 1904-ig volt az Eötvös Collegium tagja, olyan társakkal, mint Kodály Zoltán, Horváth János, Szekfü Gyula, Kuncz Aladár, Laczkó Géza, Balázs Béla. 1904-ben jelent meg nagy elismerést kiváltó tanulmánya A vogul szóképzés, amellyel elnyerte az Akadémia fiatal nyelvészeknek kiírt Sámuel-díját, s így ösztöndíjasként egy teljes évet tölthetett Franciaországban. Önéletírásában, az Életeim-ben részletesen beszámol párizsi könyvvásárlásairól. Ízelítöül:

„A Szajna-parti bouquiniste-ek, különösen a balpartiak, általában mind ismertek engem. Sokkal valóságos barátságban voltam. Alig volt nap, hogy ne szimatoltam volna szét a ládáikban [...] Sok vacsorám és sok ebédem valorizáltam át könyvre.”2 Máshol: „A könyv, meleg sugárzású egykorú kötésben megvolt. Ára:

${ }^{1}$ Szabó Dezső könyvtárának 1945-1949 közti sorsát a Vallás- és Közoktatásügyi Minisztérium (VKM) iratanyagára támaszkodva feldolgozta: Keresztes Csaba, Szabó Dezsö könyvtára = ArchivNet, 2005/4; az MTA Bölcsészettudományi Kutatóközpont Irodalomtudományi Intézet Archívuma könyvtárra vonatkozó dokumentumaiból válogat: A Nagyboldogasszony úttól a Ménesi útig, öszszeáll., s. a. r. Simon Zsuzsanna, Bp., Nap, 2011, 11-30; az Eötvös Collegium, majd az Irodalomtudományi Intézet könyvtára történetének egy szeletét feldolgozta: MARкó Veronika, Eötvös József Collegium könyvtára - Irodalomtudományi Intézet Eötvös Könyvtár, Egy válságos évtized története (1945-1955) = Magyar Könyvszemle, 2010, 226-241, és MARKó Veronika, Hogyan lett az Eötvös Collegium könyvtárából az Irodalomtudományi Intézet Eötvös Könyvtára = Lustrum, eds. László Horváth et al., Bp., Typotex, Eötvös Collegium, 2011, 220-235.

${ }^{2}$ Szabó Dezső, Életeim I-II, Bp., Szépirodalmi, 1965, II. kötet (a továbbiakban Életeim II) 126; életrajzához: Nagy Péter, Szabó Dezső, Bp., Akadémiai, 1964 (a továbbiakban NAGy 1964), és Budai Balogh Sándor folyóiratcikkei - összegyüjtve megjelent: BudAI BALOGH Sándor, ,,Megtö- 
hatvan frank. A szívem a nyeldeklőm alá csuklott fel. Abban az időben ez az összeg igen tekintélyes volt egy könyvért [...] De a könyv, a nő és a szép vidék hívásainak nehéz ellenállni."”3

Hazatérésekor már egy héttel korábban megvette vonatjegyét, nehogy könyvkereskedőknél hagyja az erre félretett pénzét is, s kilenc hatalmas ládában küldette Budapestre egy szállítóvállalattal gyüjteményét. ${ }^{4} \mathrm{Az}$ I. világháborúig még négy nyarat töltött Párizsban, $\mathrm{s}$ mindegyik útjáról rengeteg könyvvel tért vissza.

„Háború előtti élete valóságos bolyongás egyik vidéki városból a másikba. Egy állandó pontja van, életének egy forró kiterjeszkedése: Párizs, és rajta keresztül a világmúveltség legszebb álmai. Szegényes útipoggyászában Párizsból hozta hangszereit, amelyeken ezeket az álmait megjátszhatta: a nyugati Európa majd mindegyik nyelvén írott könyveit" - foglalta össze Kuncz Aladár ezeket az éveket. ${ }^{5}$

„Bolyongásainak” oka, hogy botrányai miatt évröl évre más iskolába helyezték: Budapestről Székesfehérvárra, Nagyváradra, majd Székelyudvarhelyre, ahonnan fegyelmi ügye miatt került 1913-ban Sümegre. Az itteni négyosztályos reáliskolában tanítani valóságos büntetés volt, ${ }^{6}$ mégis - itt is - fegyelmit kapott 1914 elején vallásgyalázás miatt, ${ }^{7} \mathrm{~s}$ szeptembertől Ungvárra kellett költöznie. „A háború első három évében Ungvárt voltam tanár" - kezdi Ölj! címü elbeszélését, majd arról ír, hogy ezekben az években ismerte meg a szenvedést, az éhezést, gyakran bujdosott a hitelezők elől. ${ }^{8}$ A szakirodalom itteni éveiről nem sokat tud, ${ }^{9}$ ezért értékes dokumentumok az Eötvös Collegium levéltárában őrzött levelei, melyeket Bartoniek

röm a villámokat”, Tanulmányok, írások Szabó Dezsőről, Bp., Püski, 2004 (a továbbiakban BuDAI BALOGH 2004), valamint újabban (bár a könyvtárra vonatkozóan nem találtam benne újdonságot, de életrajzi adatokban igen gazdag): Szöcs Zoltán, Szabó Dezső enciklopédia, Bp., Kairosz, 2011. Irodalomtörténeti megítéléséhez: VERES András, Szabó Dezsö újraértékelése = Jelenkor, 2013/1, 61-68.

${ }^{3}$ Életeim II, 85-86.

4 Életeim II, 135.

${ }^{5}$ Kuncz Aladár, Szabó Dezsö = Ellenzék, 1923. július 22.; kötetben: Az elsodort író, In memoriam Szabó Dezső, vál., szerk. Gróh Gáspár, Bp., Nap, 2002, 150; ill. Kuncz Aladár, Erdély az én hazám, Válogatott tanulmányok és cikkek, s. a. r. Pomogáts Béla, Csíkszereda, Pallas-Akadémia, 2013, 152-153.

6 „Sümeg a legbüntetőbb állomás” (Szabó Dezső, Segítség!, Bp., Püski, 1997, 207). - „Ide tettek, ebbe a derék falucskába, ahol csak véletlen, kegyúri szeszély, hogy négyosztályos középiskolát csináltak egyszer. Innét nincs hova büntetésböl elhelyezni..." (KAFFKA Margit, Reggeli kávé = Pesti Napló, 1917. 285. sz.; kötetben: KafFKA Margit, Álom, Kaffka Margit kiadatlan elbeszélései, Bp., Franklin, é. n., 73).

7 Degré Alajos, Szabó Dezső sümegi fegyelmi ügye = Irodalomtörténeti Közlemények, 1966, 591-593; Életeim II, 577-583.

${ }^{8}$ Szabó Dezső, Ölj! és egyéb elbeszélések, Bp., Genius, 1921, 11.

9 Nagy 1964, i. m. 101; Pomogáts Béla, Szabó Dezső Ungváron = Együtt, 2006/1, 13-17. 
Gézához, az intézmény első igazgatójához írt. ${ }^{10}$ Szabó Dezső igen nagyra becsülte BG urat (a collegisták így nevezték), diákévei után is házitanítóskodott lányai mellett (Juliska kezét meg is kérte). ${ }^{11}$ Évekkel később nehéz helyzetében hozzá fordult segítségért. A legkorábbi levelet teljes egészében betühíven idézem: ${ }^{12}$

\section{„Méltóságos Uram!}

Ne méltóztassék tolakodásnak venni levelem. Nem a volt hallgatót akarom feltámasztani, igen szemtelen insistance volna ez részemröl. Mint egészen idegen könyvvigéc vagyok bátor egy üzletet ajánlani.

Két év óta mintegy ezerkétszáz - valószínüleg több - kötetből álló könyvtáram a sümegi Népbanknál van zálogba téve. A könyvtár francia, magyar, angol, német, olasz, spanyol szépirodalmi, esztétikai, történelmi, filozófiai és szociológiai könyvekből áll. Bár a könyvek nagy részét antikvárice jutányosan vettem, mégis több - tízezer koronánál aligha kevesebb pénzemben áll.

Ez a könyvtár nekem már semmiképpen nem kell, én ilyen terhet többé nem bírok el. A bank most rám írt, hogy helyi viszonyai miatt s a könyvek érdekében is, most már többet igazán nem várhat, $\mathrm{s}$ ha három hét alatt nem intézem el a dolgot, ott Sümegen elárverezteti.

A könyvtár a banknál kétszázharminc koronáért van letéve, de a hivatalos költségekkel kiváltása kb. háromszáz K.ba kerülne.

A köv. ajánlatot bátorkodom tenni. Ha Méltóságod a könyvtár megszerzését az intézetre hasznosnak véli, méltóztassék a banktól kiváltatni és elhozatni s itt személyes megtekintés után nekem hét-nyolcszáz K. vételárt fizetni. Ha azonban ez az összeg a megtekintés után soknak találtatnék, Méltóságod bármilyen becslését elfogadnám. Becslés csakis személyes megtekintés után volna lehetséges, mert semmiféle katalógusom nincs.

Igaz, hogy a könyvek túlnyomó része a Koll. könyvtárában megvan, de ezek talán több példányban is szükségesek $\mathrm{s}$ akad nem egy érdekes kiadás is.

Ha Méltóságod ajánlatom elfogadhatónak találja, igen kérem lehetőleg rögtöni válaszát, mert a gyertya kissé körmömre égett $\mathrm{s}$ író ismerőseim egy másik megoldást is ajánlottak, ami némi időt vesz igénybe.

Bpest, 1916. aug. 1

Maradok méltóságodhoz

mély tisztelettel

Szabó Dezső

I. Bécsikapu tér 1 sz. fdsz.2."

${ }^{10}$ ELTE Eötvös József Collegium Mednyánszky Dénes Könyvtár és Levéltár (a továbbiakban EJC MDL) 38. doboz 64/a dosszié. (Bartoniek 1895-től 1928-ig volt a Collegium igazgatója.)

11 Életeim II, 142-145; NAGY 1964, i. m. 33.

${ }^{12}$ EJC MDL 38. doboz 64/a dosszié 8. - A budapesti cím oka: későbbi leveleiből kiderül, hogy Budapesten nyaralt. 
Az ezt követő levélváltásból kiderül, hogy $\mathrm{BG}$ elfogadta régi diákja ajánlatát: kifizette a Sümegi Népbank követelését (371 K 90 f) és ezen felül a könyvek vételáraként 800 koronát adott Szabó Dezsőnek. ${ }^{13} \mathrm{Az}$ egykori tanítvány augusztus 6-án jelzi Bartonieknek, hogy a könyveket annak idején hét nagy deszkaládában szállították a bank raktárába, megerősítés után ezekben vonatra tehetők, a banktisztviselők sürgetik is ezt, „,nehogy valami új katonaszállítás miatt hetekre kidobják valamelyik állomáson.” Megírja még: „a lefoglaláskor vettek fel hivatalosan egy katalógust, mely ott van hivatalos letétben. Ez ugyan mind ilyenekből áll:

Szerző: Tomo Primo

Munka c. Secunda edizione etc.

de ők nem tudják, hogy ilyen s félnek tőle."14

Önéletrajzi regénye, az Életeim 1914-ben, sümegi tartózkodása közepén szakad meg (írását 1944 decemberében kénytelen abbahagyni, amikor az ostrom kezdetén végleg levonul a pincébe), így sem könyvei 30 éve történt lefoglalásáról, sem az 1916-os kiváltásról nem tudhatunk már meg semmit belőle. Vagy mégis? Még székelyudvarhelyi tanárkodása idejéből (1912-ből!) érdekes történetet mesél el: egy szabócég 3600 koronára perelte az addig neki készített ruhákért (különösen fiatal korában nagy hangsúlyt fektetett öltözködésére, megjelenésére), s lefoglalták egyetlen vagyonát, szép és értékes könyvtárát. „Megkezdték elkészíteni a könyvek listáját. De a francia, olasz, angol, német, spanyol, finn könyvek dzsungelében már az első kötetnél megakadtak. Ügyvéd, végrehajtó, segéd tanácstalanul néztek egymásra, én pedig egy karszékből nem minden humor nélkül szemléltem őket." Végül az ügyvéd könyörgésére ráállt, hogy lediktálja a könyvek szerzőjét és címét: „lediktáltam egy éktelen hosszú listát, melyen néhol a megjelenési helyet, néhol a címet vagy annak egy részét tettem meg szerzönek, a szerzőt vagy a megjelenési helyet címnek és így tovább. Az ügyvéd kövér megelégedéssel távozott kíséretével."

Az ezt követő bírósági tárgyalás vádbeszédének egy jellemző mondata: „mint írónak, mint tanárnak, lehet húsz, lehet harminc, lehet negyven kötetre szüksége, de nem több mint kétezer kötetre, melyek különben is a legkülönbözőbb szakmákból valók, melyek öt nem is érdekelhetik".

Szabó Dezső a tárgyaláson visszaemlékezése szerint önmagát védte - a bírót meggyőznie és az ügyvédet megaláznia azzal sikerült, hogy elővetette a lefog-

${ }_{13}$ EJC MDL 38. doboz 64/a dosszié 12. - A Sümegi Népbank 1916. aug. 4-i levele BG-nek: 371 K 90 fillér követelésük ellenében adják ki a lefoglalt könyveket; 13. „Nyugtatvány 800 Koronáról, mely összeget a Br. Eötvös J. Kollégium pénztárától később kiállítandó jegyzék szerint átadott könyvek vételára fejében átvettem. Bpest, 1916. aug. 21-én Szabó Dezső"; valamint 19. doboz 55. dosszié (Szabó Dezső személyi anyaga): 7. Postai föladóvevény a Sümegi Népbanknak 371K 90f-röl 1916. aug. 7. dátumbélyegzővel.

${ }^{14}$ EJC MDL 38. doboz 64/a dosszié 11. Szabó Dezső levele BG-nek 1916. aug. 6. - sajnos nem maradt fenn sem ez a lefoglaláskor felvett „ál”, sem bármilyen „valódi” könyvlista. 
lalás könyvjegyzékét, s elkezdte azt fordítani: „Szerző: Második kiadás, Cím: Maimbourg Lajos. Megjelenési hely: A lutherizmus története [...] A bíró rögtön elutasította a keresetet, és feloldotta a lefoglalást."15

Barátja (szerelme? ${ }^{16}$ ), Kaffka Margit Reggeli kávé címü, 1917-ben megjelent novellájában mutatja be Szabó Dezső könyvszeretetét. Az író egy sümegi reggelen, mielőtt tanítani indul, szobaasszonyával beszélget, collegiumi éveitől egész addigi életét elmeséli (párizsi utazásai, tanárkodása...), utal a vallásgyalázás miatti fegyelmire, majd ezt mondja: „Akkor már több mint a fele fizetésem lefoglalták adósságba, a könyvtárom, ... igen, nyolc-tízezer koronát egy pesti nyilvános könyvtár ígért érte, de ezt nem, ezt az egyet nem! Egyetlen kötetét se! Ennyi a morál és az erő maradék morzsája bennem!"17 (Kaffka novellája három évvel a lefoglalás, $\mathrm{s}$ egy évvel a könyvek Collegiumba kerülése után jelent meg!)

Úgy tünik, első könyvtára elvesztése érzékenyebben érintette, mint későbbi, a gyüjtőszenvedély mellett sokszor üzleti megfontolású könyveladásai-vételei. Erre utalnak Kaffka Margit idézett sorai, s egy 1918-as levelének részlete is: „A háborús évek teljesen tönkretettek. Elvitték könyvtáram és lerongyoltak." 18 Vajon, ha folytathatta volna önéletrajzi regényét, szembe tudott volna nézni e nagyon nehéz időszakkal, az első világháború éveivel, tetézve legbecsesebb tulajdona, gondosan gyüjtött könyvtára elvesztésével?

A 20-as, 30-as évek collegistái még tudtak erről a könyvanyagról, hiszen gyakran forgatták, mégis mindössze két rövid utalást találtam Szabó Dezső korai könyvtárának a Collegiumba kerülésére: egyrészt Féja Géza említi meg a Szabadcsapat-ban, másrészt Borzsák István írja meg, hogy Tacitust az ő Firmin-Didot kiadású kötetéből olvasta elöször 1933 nyarán. ${ }^{19}$

Milyen kötetekből állt ez a könyvtár? 1914 elején a Nyugat-ban megjelent Beteg a könyvek között címü novellájában részletesen bemutatja:

„A falakat magas könyvszekrények takarják, melyeket minden színü és formájú könyvek zsúfolnak tele. A könyvek különös, gazdájukhoz szabott rendben

15 Életeim II, 477-480. - Az a motívum, hogy a végrehajtók a müvek (bár itt szobrokról van szó) listáját nem tudják összeírni, s Szabó Dezsőnek (Boór Bálintnak) kell diktálnia, a Segitség című regényben is megjelenik (Szabó Dezső, Segítség! Bp., Püski, 1997, 189).

16 Bodnár György, Kaffka Margit, Bp., Balassi, 2001, 62-64.

17 KaffKa Margit, Álom 75.

18 NAGY 1964, i. m. 186.

19 „Az első világháború folyamán könyvtárának az eladására kényszerült, az Eötvös Kollégium vette meg, ismertem a gyüjteményt, csupa jelentős müből állott, Szabó Dezső kiválasztó ösztöne tökéletesen dolgozott.” - FÉsA Géza, Szabadcsapat, Bp., Szépirodalmi, 1965, 86; BorzsÁK István, A klasszika-filológia az Eötvös Collegiumban = Antik Tanulmányok, 1985-86, 251; ill. újraközlése: Borzsák István, Dragma I. kötet, Bp., Telosz, 1994, 392; az említett mü: TACite, Oeuvres complètes, publ. par M. NisARD, Paris, 1842 (Szabó Dezső possessor bejegyzéssel). - Nagy Péter, Szabó Dezső monográfusa diákként, majd kutatóként is használta a könyvtárat (s a régi Collegium iratanyagához is hozzáférhetett), mégsem említi sem a lefoglalást, sem az első gyüjtemény könyvtárunkba kerülését. 
szomszédjai egymásnak. Tertullianus és Szent Jeromos közt Zola-kötetek, Szent Ferenc mellett Van Lerberghe és Jammes, Butler Hudibras-a mellett $A$ magyar alkotmány története, Comte és Marx között Szent Ágoston, századokon vénült bör-fóliánsok közt a Mercure de France sárga kötetei. És ez a bizarr egymásmellettiség mégis egy lélek titkos egységét adja."Majd Dante, Keats, Whitman iránt lelkesedik. ${ }^{20}$

Olyan szerencsés helyzetben vagyunk, hogy - bár lista nem maradt fenn immár 120 éve folyamatosan müködő könyvtárunk eredeti leltárnaplóiból rekonstruálható a megvásárolt könyvanyag. Maga Bartoniek Géza írta be az első tételhez: „Szabó Dezső könyvtára”, a „szerzés módja” rovatba pedig a „vétel 1916 (SzD)" megjegyzést. Sok kötetben találunk possessor bejegyzést - néhol évszámmal (1901 és 1912 közöttiek), helymegjelöléssel (Szhely, illetve Székelyudvarhely, Sümeg, Paris stb.).

Szabó Dezső saját bevallása szerint nyolc nyelven olvasott, ${ }^{21}$ tükrözi ezt könyvtára összetétele is: csaknem fele (365 kötet, 287 mü) a francia irodalom és irodalomtörténet, $\mathrm{kb}$. egynegyede az angol, spanyol, olasz irodalom, valamint a finnugor irodalom és nyelvészet körébe tartozik. A fennmaradó negyeden a magyar irodalom, a történelem, filozófia, lélektan osztozik, valamint néhány szótár, Biblia ${ }^{22}$ (német nyelvű mindössze hat mủ, pl. Nietzschét is francia fordításban olvasta inkább).

A könyvtár részletes tartalmi elemzése külön tanulmány feladata lehetne, itt épp csak megemlítem, hogy a gyüjtemény számos darabjához találhatunk az író életmüvében (az Életeim párizsi könyvvásárlásairól beszámoló részleteiben, folyóiratcikkeiben, fennmaradt leveleiben) kapcsolódó hivatkozást, érdekes történetet. ${ }^{23}$

Az Életeimben beszámol pl. arról, hogy A futurizmus, az élet és irodalom (helyesen: müvészet) új lehetőségei címmel a Nyugat-ban megjelent tanulmányát valaki lefordította, s eljuttatta Marinettinek, aki könyvcsomagot küldött neki hosszú levéllel, melyben megköszöni írását, s kéri, foglalkozzon továbbra is a futuriz-

20 SzABÓ Dezső, Beteg a könyvek között $=$ Nyugat $, 1914 / 5,299$.

${ }^{21}$ NAGY 1964, i. m. 26.

${ }^{22}$ A gyüjtemény egyik legrégibb kötete egy 1626-os első kiadású KáLDI György Biblia.

${ }^{23}$ Néhány példa: Életeim II, 559: 1913 őszén egy Sümeg környéki erdőben VAN LERBERGHE, La Chanson d'Ève kötetét olvasta - a mü „Didier Szabó 1911” possessor bejegyzéssel itt áll könyvtárunk polcán 1916 óta. Victor Hugo versei iránti lelkesedését is többször megírta, mind első, mind utolsó könyvtárából több kötetet őrzünk. Bauer Hilda, Balázs Béla húga visszaemlékezése párizsi találkozásukra: „Egyszer egy Victor Hugo verskötetnek [...] első kiadását találta meg. Majd megörült örömében [...] egész du. olvasott, szavalta, kiabálta Victor Hugo verseit. Rajongott érte akkoriban.” (BAUER Hilda, Emlékeim, MTA Filozófiai Intézet Lukács Archívum, Bp., 1985, 18-19.); Életeim II, 123: ,egy hétig minden kora délelőtt felmentem a Notre Dame tornyának a tetejére [...] Mindig magammal hoztam Baudelaire-t, és ha kiámultam magamat, itt, Párizs nagy horizontjában tanultam meg két-három versét könyv nélkül”, majd két idézet következik a Les fleurs du malból. A kötet, amelyet valószínűleg fölvitt magával: BAUDELAIRE, Charles, Les fleurs du mal, Paris, Calmann-Lévy, é. n. Szabó Dezső 1906 Pa[ris] possessor bejegyzéssel kézbe vehető könyvtárunkban. 
mussal. ${ }^{24}$ A Nyugat-ban abban az időben megjelent cikkei szerint visszaemlékezése nem pontos! Marinetti Le Futurisme címú kötetét Párizsban egy könyvárusnál vette, s az erről írt kritikája hatására küldte meg a futurista a könyvtárunkban a mai napig őrzött Le Monoplan du Pape kötetét, melyet Szabó Dezsőnek dedikált (,à Szabó Dezső hommage de F T Marinetti”) - derül ki az ez utóbbi müről írt recenziójából. ${ }^{25} \mathrm{Az}$ általa említett nagyobb lélegzetü futurizmus-cikke pedig csak a következő év elején jelent meg.

A leltárnaplóban 600 mü (770 kötet) szerepel, tehát a levélben említett 1200 kötet vagy túlbecsült, vagy elképzelhető, hogy a legkedvesebb darabokat Szabó Dezső visszakapta Bartoniektől. (Ezt valószínűsíti, hogy arányaiban nagyon kevés a magyar irodalom a könyvtárunkba került anyagban.) Kétségtelen, hogy az Életeim-ben említ olyan köteteket, amelyeket első párizsi útján vett, s még 1944ben is megvannak könyvtárában, így pl. egy 1735-ös Desprez kiadású bőrkötéses Szent Ágostont, amelyet csak halála után kapott meg könyvtárunk (ugyanakkor egy korábbi kiadást már az 1916-os vásárlással). ${ }^{26}$ Szintén ezt támasztja alá, hogy Beteg a könyvek között címü novellája korábban idézett részletében több olyan mü szerepel, amelyeket nem vett Bartoniek állományba. (Butler csak utolsó könyvtárából került hozzánk, vagy említhetjük Marxot - ebben a gyüjteményben nem, az 1924-ben eladásra szánt könyvei között viszont már szerepel. ${ }^{27}$ )

\section{A második}

A korabeli közéletben, lapokban könyvei 1924-es kiárusítása nagy nyilvánosságot kapott. Hogyan is jutott el idáig? Sajtó útján elkövetett izgatás és nemzetgyalázás miatt börtönre és komoly pénzbüntetésre ítélték, a Kúria az ítéletet felfüggesztett fogházra, s a pénzbüntetést felére csökkentette, de így is kilátástalannak érezte helyzetét. Elhatározta, hogy „,kivándorol”. Kifizette tartozásait, eladta müvei kiadói jogát a Stádiumnak, majd kiárusította Szirtes úti lakásán 6000 kötetes könyvtárát. ${ }^{28}$

${ }^{24}$ Életeim II, 462-463; SzABó Dezső, A futurizmus, az élet és müvészet új lehetőségei = Nyugat, 1913/1, 16-23.

${ }_{25}$ Az említett kötet: F. T. Marinetti futuriste, Le Monoplan du Pape, Paris, E. Sansot \& Cie, 1912; Szabó Dezső, Marinetti, Le futurisme = Nyugat, 1912/14, 156; Szabó Dezső, Marinetti, Le monoplan du pape = Nyugat, 1912/16, 298-299.

${ }^{26}$ Életeim II, 19. - Nagy Péter monográfiájában megemlíti, hogy egy fennmaradt feladóvevény tanúsága szerint Székelyudvarhelyről Sümegre 8 láda könyvvel költözött, amit ő legalább 3000 darabnak gondol (NAGY 1964, i. m. 84). Szabó Dezső az Életeim 1912-es könyvlefoglalási történetében 2000 kötetet említ (Életeim II, 477). Ha hihetünk e becsléseknek, akkor nem a teljes könyvtárat foglalták le, esetleg már korábban is értékesített köteteket...

27 TAXner Ernő, Szabó Dezső kéziratos könyvtár-,, lajstroma" = Irodalomtörténet, 1972/3, 725.

${ }_{28}$ Budai Balogh Sándor, Szabó Dezső ismeretlen naplója = Irodalomtörténeti Közlemények, 1985, 688-708; NAGY 1964, i. m. 365-369. - A könyvkiárusítás történetét megírta Segítség! címü regényében (SzABó Dezső 1997, i. m. 451-458). Cs. Szabó László segédkezett a kiárusításnál, sze- 
Amiért megemlítjük e gyűjteményt (hisz ebből a Collegium nem vásárolt): Szabó Dezső listát írt eladásra szánt könyveiről (ma a Petőfi Irodalmi Múzeum örzi). Taxner Ernő e „lajstrom” alapján elemezte a könyvtár összetételét,$^{29} \mathrm{~s}$ feltette a kérdést: az újabb irodalomhoz tartozó müvek vajon miért zömében 1917 és 1924 közötti megjelenésűek és nem első vagy legalábbis korábbi kiadások. Feltételezései: a korábbi kötetek az évenkénti költözésekkor eltüntek, esetleg megtartotta a legértékesebb darabokat stb. Utóbbi gondolata azóta beigazolódott: az író még a kiárusítás előtt kiválogatta a legbecsesebb köteteket, s ezeket Szalay József rendőrfőkapitány őrizte meg számára. ${ }^{30}$ De a fő ok mégiscsak az, hogy az 1916-os kényszerü könyvtáreladás után újra kellett építenie könyvtárát.

\section{Az utolsó}

A könyvkiárusítás után, 1924 őszén Olaszországba, majd Párizsba utazott, de a következő év márciusában már vissza is tért - Szegedre. „Kilenc láda könyvem utazott velem. Háromszázhúszmilliót költöttem öt hónap alatt!" ${ }^{31}$ Hazatérte után befejezte Segitség! címü regényét, melynek a kiadói jogáért kapott összegből egyből ismét Párizsba ment, s szép és drága könyveket vásárolt. Ezután már csak egyszer, 1928-ban járt Párizsban.

A 30-as években a Városmajor utcában bérelt lakást. A kortársak visszaemlékezése szerint az egyetlen szobában egymásra rakott ládák alkották a könyvállványt a mennyezetig. Az író állandóan rendezgette könyveit: ahogy az Eötvös Collegiumban, itt is külön csoportban volt a magyar szépirodalom (ez volt a leggazdagabb), a külföldi szépirodalom, a történelem, vallás, természettudomány, szótárak. ${ }^{32}$

1939-ben költözött utolsó, József körúti lakásába, ahol az új könyvpolcok valóságos könyvutcákat képeztek, s a falakat is mennyezetig fedte a 13000 kötet. ${ }^{33}$ Sürün látogatta az antikváriumokat, Stemmer Ödön visszaemlékezésében megírja, hogy egy-egy vásárlásakor annyi könyvet választott ki, hogy taxival kellett hazaszállíttatnia. S még egy fontos gondolata: „A németeket utálta. Idegen nyelvü készleteim böngészése közben német könyvhöz soha hozzá nem nyúlt." 34 Márpedig mégiscsak összegyüjtött rengeteg német nyelvü szakirodalmat (föleg

rinte nem anyagi szükségből, hanem hordozhatatlan mérete miatt vált meg könyvtárától (Cs. SzABÓ László, Levél a szerkesztöhöz Szabó Dezsőről = Új Látóhatár, 1960, 460-461).

29 TAXNER 1972, i. m. 724-733.

30 Budai Balogh Sándor, Szabó Dezső ismeretlen naplója = Irodalomtörténeti Közlemények, 1985, 695. - „A nagy magyar auktorok mind megvannak még és megvan Saint-Beuve összes munkája!" (Budai BAlogh 2004, i. m. 63.)

31 Budai Balogh Sándor, 1985, i. m. 707; Uő 2004, i. m. 77.

32 Budai Balogh Sándor, Szabó Dezső Ludas Mátyás-füzetei=Irodalomtörténeti Közlemények, 1982, 219; Uő 2004, i. m. 141.

${ }^{33}$ Budai Balogh 1982, i. m. 227; Uő 2004, i. m. 154; Füsi József, Szabó Dezső = Beszélő házak, Hatvany Lajos szerk., Bp., Bibliotheca, 1957, 253.

34 Stemmer Ödön, Egy antikvárius visszaemlékezései, Bp., Szépirodalmi, 1985, 275. 
a filozófia, pszichológia, művészettörténet, földrajz és történelem területéről), s szépirodalmat is - igaz, ez teljes könyvtárát tekintve elenyésző: Goethe, Schiller, Hauptmann, Lessing gyüjteményes kiadásai maradtak ránk.

Az Eleteim egyik utolsó kitekintése a múltból a mára, azaz 1944. november 19-re: „A köd alig ritkul, csak éppen hogy látok írni közvetlenül az ablak mellett. A kályhában táncoló lángok rá-rávezetik fényüket egy-egy könyvsorra. Nevek csillognak fel egy pillanatra a szoba hígult homályából: Szent Ágoston... Dante... Shakespeare... Cervantes... Michelangelo... Petöfi..."35

Az író 1945 januárjában hunyt el a József körúti ház pincéjében. Végrendeletet nem hagyott hátra, csak müvei jogait ígérte több írásában egykori iskolájának, a Kolozsvári Református Kollégiumnak. ${ }^{36}$

Hőgye Mihály (akit a MADISZ hatalmazott fel minden Szabó Dezső hagyatékával kapcsolatos ügy intézésére az ostrom után) visszaemlékezésében ${ }^{37}$ beszámol a lakásban tapasztalt állapotokról: meglepte a könyvek mennyisége, s hogy az elmúlt hónapok eseményei ellenére viszonylag rendben álltak a polcokon - nyelvek, tudományterületek szerint csoportosítva. Azonnal lépéseket tett a könyvtár szakszerü katalogizálása érdekében, de mielött a felkért bibliográfusok hozzákezdhettek volna a munkához, a lakás két szobájába bérlőket költöztettek, így a harmadikba kellett mindent összezsúfolni. Az elöljáróság emberei az átpakoláskor „leltárba vették” a könyveket: „tíz nagyobb, húsz kisebb könyv”, kezdték a legfelső polccal. Ezt látva döntött úgy Hőgye, hogy a lakásban talált, $\mathrm{s}$ általa már korábban összeszedett kéziratokat - a zavaros körülményekre tekintettel - magához veszi (néhány személyes tárggyal együtt), s örzi mindaddig, míg biztosítottnak nem látja azok megfelelő helyre kerülését.

${ }^{35}$ Életeim II, 443.

36 „Halálom percétől kezdve minden, bárhol található írásom, összes műveim minden joga a kolozsvári református Kolégyomé. Tehát: minden müvem magyar nyelvű kiadójoga és minden müvem minden szerzői joga (fordítás, film, dramatizálás, rádió stb.) [...] A mostani kiadásai műveimnek rosszak, tele vannak lényegrontó hibákkal. Én alkonyodó napjaim ellátására természetesen ki fogom adni egyik-másik művemet. De a nagy kritikai kiadását összes müveimnek úgy fogom elökészíteni éveken át teljes filológiai és keletkezéstörténeti jegyzetekkel: hogy azt majd az Alma Mater adhassa ki rögtön, halálom után. Azt akarom, hogy azonnal nagy összeghez jusson egy páratlanul hiteles és részletes tájékoztatású kritikai kiadás első piacrabocsátásával.” (Szabó Dezső újabb müvei 60, Bp., 1940. július-november hava, 72-75; A Szabó Dezső Füzetek, vagy Ludas Mátyás-füzetek a 30. szám után Szabó Dezső újabb müvei címmel jelentek meg.) - Életében utolsó nyomtatásban megjelent írásában is a Református Kollégiumra hagyta müveit: Búcsú és testamentum (Magyar Ünnep, 1944. nov. 12.), újraközlése: Confessio 1979/4, 106-107. Itt említést tesz a könyvtárról is: „Körülbelül tizenháromezer kötet nagy értékű könyvtáramat, arra az esetre, ha ezerkilencszáznegyvenöt előtt halnék meg, a budapesti Fővárosi Könyvtárra hagyom. De ez a hagyakozás nem érinti azt a szabadságomat, hogy addig könyveimmel másként rendelkezzem. Kérem a Fővárosi Könyvtárat, imádkozzék, hogy ne kapja meg könyveimet."

${ }^{37}$ HöGYe Mihály, Szabó Dezsö-emlékek = Hitel, 1990/7, 37-39; a személyes beszélgetéseik során elmondottakról beszámol Budai BaLogh Sándor, A Szabó Dezsö-életrajz története = SzABÓ Dezső, Életeim, Bp., Püski, 1996, 909-913. 
Hivatalos végrendelet hiányában a könyvek jogilag az örökösöket illették volna, akik azonban nem tartottak rájuk igényt, így a Vallás- és Közoktatásügyi Minisztérium 1947 elején megvásárolta az egész könyvállományt. A miniszter ekkor Keresztury Dezső (egyben az Eötvös Collegium igazgatója), aki közvetlenül a háború után már Halász Gábor és Balogh József könyvtárát is a Collegiumba mentette. ${ }^{38} \mathrm{Az}$ ő és az általa a Felsőoktatási és Tudományos Főosztály élére kinevezett Zsebők Zoltán hatékony együttmüködésével sikerült a könyvtárat megszerezni azzal a tervvel, hogy nagyobbik részét a Kolozsvári Református Kollégium kapja meg (ügyeit ideiglenesen a Kolozsvári Egyetemi Iroda intézte), kisebbik része pedig az Eötvös József Collegiumba kerül. ${ }^{39}$

A könyvek átszállítására, őrzésére, leltározására Tomasz Jenő, az Eötvös Collegium aligazgatója kapott megbízást 1947 júliusában, az ö - a minisztérium számára készített - beszámolójából részletes képet kapunk a szállítás és feldolgozás nehézségeiröl.

„A felnyitott szobába bemenni nem lehetett; könyvpolcok, szekrények, székek, zenélő órák s rengeteg könyv egymás hegyén-hátán, teljes összevisszaságban volt a szobában felhalmozva, úgy, hogy a könyveket lépésröl-lépésre kellett kibányásznunk onnan."40

Az átszállítás (kosarakban le a 3. emeletről az autóhoz, s fel a Collegium épületébe a növendékek és alkalmazottak segítségével) két teljes napot vett igénybe kínzó kánikulában, úgyhogy Tomasz Jenő alapos elszámolása 6 liter bort is tartalmazott a kemény munka jutalmául. Mivel a könyveket teljesen összekeverve tudták csak a kosarakkal átvinni, elhelyezték azokat a földszint 10. szobában (ma az Irodalomtudományi Intézet igazgatói tárgyalószobája Sőtér István könyvhagyatékával), majd 50-100 darabonként fölvíve az első emeleti díszterembe (a mai olvasóterem) az állomány minden egyes darabjáról katalóguscédulát vettek föl a munkát vállaló kollégisták. Ennek alapján történt aztán a betürendezés és a többkötetes müvek összeválogatása.

Az író és a kortársak által is 13000 kötetesre becsült könyvtárból a dokumentumok tanúsága szerint 9340 darabot sikerült megmenteni. Ebböl emelték ki a Collegium könyvtárából hiányzó müveket, a végsö összesítés szerint 2872 darabot. E kötetek leltározása 1948 öszén-telén meg is történt. A minisztériumból átküldtek 9000 darab ex librist, ezeket minden kötetbe beleragasztották. ${ }^{41}$

${ }^{38}$ Markó 2010, i. m. 237-238.

39 ZsEBÖK Zoltán, Lépcsőfokok, Szépirodalmi, Bp., 1982, 322-323. - Zsebők visszaemlékezésében azt is megírja, hogy „LT” (Lutter Tibor, a Collegium utolsó igazgatója a megszüntetés előtt) nem csökkenő makacssággal támadta a minisztériumban Kereszturyt, többek között azt is kifogásolva, hogy miért kellett Szabó Dezső könyvtárát az intézménynek adni.

${ }^{40}$ MTA BTK ITI Archívum 16. fond 56/1948: „Dr. Tomasz Jenő, Eötvös József-Collegium aligazgatójának jelentése a néh. Szabó Dezső-féle könyvtárról” (1948. január 30.), közli KereszTES 2005; SimON 2011, i. m. 14-19.

${ }^{41}$ Magyar Nemzeti Levéltár Országos Levéltár (MNL OL) XIX-I-1-h-90-3-Bp-iEö -1845681947 (1947. dec. 17.): Zsebők osztályfőnök utasítására az Egyetemi Nyomdától 9000 db ex libris 
Kisebb állományrészeket különböző intézményeknek kellett átadni, a Kolozsvári Református Kollégiumnak szánt köteteket pedig I-XXIV-ig, illetve 1-65-ig számozott ládákban helyezték el ${ }^{42} \mathrm{Az}$ anyag kisebbik részét, a 24 ládát (646 db) Malán Mihály, a kolozsvári egyetemi ügyek intézésével megbízott egyetemi tanár átvette, majd miután a Kolozsvárra szállítás ellehetetlenült (a KEI-t is felszámolták), a könyveket az Országos Könyvtári Központ kapta meg, s valószínüleg szétosztották különböző könyvtáraknak. ${ }^{43} \mathrm{~A}$ gyüjtemény nagyobb része, 65 láda (4400 db) a Collegium pincéjében várta sorsa alakulását.

Térjünk vissza még egy percre a kéziratokhoz. Hőgye Mihály a magához vett anyagot (közte az Életeim utolsó fejezeteit) édesanyjánál rejtette el, majd Párizsba utazott (külügyi titkári megbízást kapott). Mikor értesült arról, hogy Keresztury Dezső a könyveket az Eötvös Collegiumba mentette, megkérte fivérét, vigye el hozzá a kéziratokat, személyes tárgyakat tartalmazó táskát. Keresztury, miután átvette, azonnal jelezte a minisztériumnak, ahonnan azt az utasítást kapta: vegye leltárba, s örizze, míg a jog szerinti örökös megállapítható lesz. 1950 nyarán, az Eötvös Collegium megszüntetésekor a teljes (a Hőgye Mihály által megmentett, valamint a József körúti lakásban maradt és 1947-ben a könyvekkel együtt átszállított) kéziratanyagot át kellett adni az OSZK-nak, azóta ott orrzik. ${ }^{44}$

A felszámolt Collegium gyüjteménye az Akadémiai Könyvtár kezelésébe került, annak fiókkönyvtáraként maradhatott eredeti helyén. Az ekkortól az MTA Eötvös Könyvtár nevet viselő intézmény élére az Akadémiáról kinevezett Szöke Sándor könyvtárvezető kétszer is kérte felettesét, Scher Tibor főkönyvtárost, hogy az anyagból hiányait pótolhassa (a megnövekedett olvasószám miatt szükség volt a kötetekre).

„Szabó Dezső könyvtárának nagyobbik felét, kb. 6.500 kötetet, a kultuszminisztérium 1947-ben az Eötvös Kollégiumban raktározta el. Az az intézmény (a Kolozsvári Iroda), amelyet a könyvtár gondozásával később megbíztak, idöközben megszünt. A könyvek további rendeltetése felöl azóta semmiféle hatóság-

címke $(6 \times 9 \mathrm{~cm}$, enyves háttal) sürgős megrendelése ,,a mellékelt minta szerint”. Sajnos arról, hogy az ex libris kinek a munkája, egyelőre nem sikerült sem a forrásokból, sem az egykori kollégistáktól, de még az „ex libris szakértőktől” sem semmit megtudni...

${ }^{42}$ MTA BTK ITI Archívum 16. fond 282/1948: Jelentés a Szabó Dezső-féle könyvtárról (1948. augusztus 2.) (SimON 2011, i. m. 26-27). - Már a következő miniszter, Ortutay Gyula utasítására a néprajzi vonatkozású müveket a Pázmány Péter Egyetem Néprajzi Intézete kapta meg (578), a Széchényi Könyvtár a ,fasiszta tartalmú” könyveket vette át megörzésre ( $25 \mathrm{db})$, s még 559 darab egyéb külön leválogatott könyvet kapott. A Szabó Dezső Füzeteket és a Segítség címü regény füzetlen íveit a Hartmann Testvérek Könyvkereskedése szerezte meg (1947. nov. 12. átvételi elismervény).

43 Keresztes 2005.

${ }^{44}$ MTA BTK ITI Archívum 16. fond 95/1948: Keresztury Dezső elismervénye az átvételről, tájékoztató levele Zsebőknek (SimON 2011, i. m. 19, 21.); 327/1950: 1950. aug. 17-i átadási jegyzőkönyv (csak első részét közli SıMON 2011, i. m. 32-33) a Hőgye Mihály által kimentett anyaggal a végén (az Életeim utolsó 3 fejezetével). Könyvtárunk őrzi azt a kézzel írt füzetet, amelyben eredetileg leltárba vették az összes kéziratot. 
tól semmiféle intézkedés nem érkezett. A ládákba rakott könyvtár immár ötödik esztendeje áll a nedves pincében, a megpenészedés veszélyének kitéve, készen arra, hogy használatba kerüljön." ${ }^{45}$ (A könyvtárvezető itt 6500 kötetet említ, nem veszi figyelembe az időközben más intézményeknek átadottakat. Ezek levonása után, s a 65 láda tartalmáról könyvtárunkban őrzött lista szerint is 4400 maradt ekkorra a pincében.)

A jóváhagyás után - 1952 őszén-telén - beleltároztak még 2324 kötetet. A kérvény végén Szőke javaslatot tett arra, hogy a fennmaradó állomány kerüljön szétosztásra más könyvtáraknak. Ehelyett azonban időről időre kisebb részletekben (más hagyatékokkal, adományokkal keverve, de mindig feltüntetve a leltárnaplóban, hogy Szabó Dezső könyvtárából származik) vették nyilvántartásba a megmaradt kötetek egy részét az időközben megalakult MTA Irodalomtörténeti Intézet kezelésébe került könyvtár munkatársai.

Ennek a hatalmas gyüjteménynek a részletes tartalmi elemzése igen időigényes feladat lenne. Ami felületes vizsgálat után is megállapítható, az a francia nyelvü anyag túlsúlya és a finnugor teljes hiánya ${ }^{46} \mathrm{Az}$ első könyvtárhoz hasonló arányban reprezentált az angol irodalom, történelem, filozófia, pszichológia, $\mathrm{s}$ a jelentős magyar irodalmi anyag mellett rengeteg a múvészettörténeti munka, album, földrajzi mü is. Az Ortutay Gyula kérésére az egykori Pázmány Péter Tudományegyetem (ma ELTE) Néprajzi Intézetének átadott néprajzi tárgyú müveket (lásd $42 \mathrm{lj}$.) ma is örzik az intézeti könyvtárban. A köteteket beépítették az állományba, de megismerhetőek a beragasztott ex librisről.

Összegezve: A különböző jelentések, beszámolók és a leltárnaplók adatainak összevetése után azt látjuk, hogy a Tomasz Jenő által átszállított 9300 kötetből az épületet 2000-2500 hagyta el (a Kolozsvári Református Kollégiumnak szánt anyagból mindössze a 24 ládában őrzött 646 kötet, amelyeket valószínűleg szétosztottak különbözö könyvtáraknak). Az Eötvös Könyvtár állományába nagyjából 6000 került, a fennmaradó duplumokat az időközben újjászervezett Eötvös Collegium kapta meg. ${ }^{47}$

2006-ban az OSZK Gyarapítási Osztálya ,,a kiemelkedő családok államosított könyvei visszaadásának keretében" a Fölöspéldány Központban megmaradt 29 db kötetet adott át könyvtárunknak, mint „,a hagyaték birtokosának”. ${ }^{48}$

Végül egy, a sok még mindig megválaszolatlanul maradt kérdés közül: az Országos Levéltár őriz egy nyomdai számlát 3000 darab Szabó Dezső ex librisről

${ }^{45}$ MTA BTK ITI Archívum 16. fond 115/1952: Szőke Sándor levele Scher Tibornak, közli: Simon 2011, i. m. 37-38.

${ }^{46}$ Az Életeim II 149. oldalán olvashatjuk beszámolóját arról, hogyan égette el Kuncz Aladár és Laczkó Géza társaságában 1906 augusztusában 25 ezer finnugor céduláját. Első könyvtárából a korábban vásárolt finnugor könyvei kerültek hozzánk, később azonban már nem gyüjtötte.

${ }^{47}$ Ezúton is szeretném megköszönni Bor Kálmánnak (1963-73 között volt az Eötvös Könyvtár vezetője), hogy felidézte és megosztotta velem emlékeit.

48 Tóth Józsefné gyarapítási osztályvezető 2006. 03. 22-én kelt levele Németh S. Katalin könyvtárvezetőnek - könyvtári irattár. 
1948-ból, és egy átvételi elismervényt, amely szerint az elkészült nyomtatványokat a Kelet-Európai Tudományos Intézetben vették át, ${ }^{49}$ amelyet ezután nem sokkal felszámoltak, s könyvei a megszüntető rendelettel egyúttal létrehozott akadémiai intézetek ${ }^{50}$ könyvtáraiba kerültek, de ezekben nem sikerült nyomára bukkanni Szabó Dezső könyvtárából származó anyagnak. (Nagyobb mennyiségü ex librises kötetről nem tudnak a kollégák, és az állomány jellegének, illetve a bekerülés módjának vizsgálata sem vezetett egyelőre eredményre. Kérdés, hogy 1948-ban az Eötvös Collegiumon kívül vállalta-e bármelyik intézmény Szabó Dezső „örökségét".) A 3000 ex libris ügye azért igazán izgalmas, mert a Collegiumba szállított anyagnál (9300) épp ennyivel többre (13 ezerre) becsülték egykor a könyvtár nagyságát. Ezért kérek ezúton is minden kollégát, ha nagyobb mennyiségü Szabó Dezső ex librissel ellátott könyvre bukkan gyüjteményében, jelezze!

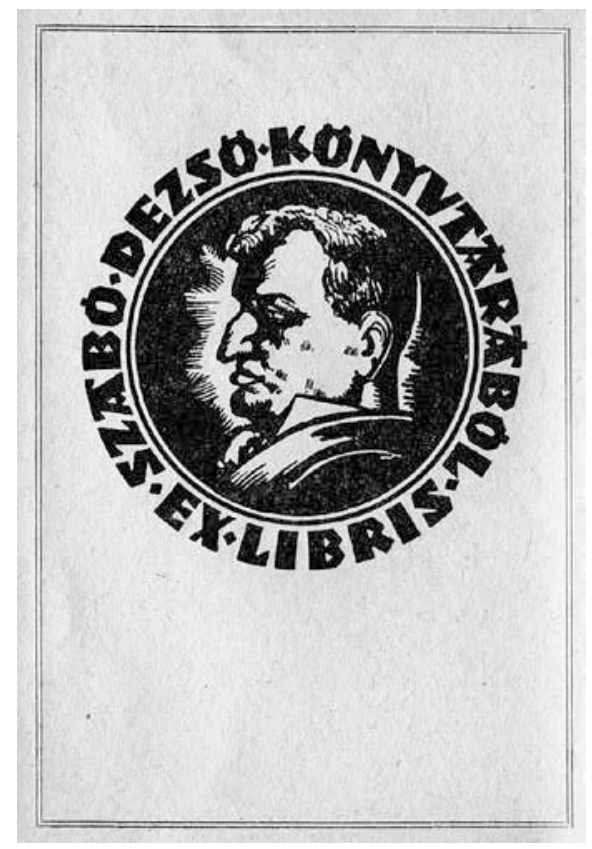

${ }^{49}$ MNL OL XIX-I-1-h-90/a-2-198942-1948: A Kelet-Európai Tudományos Intézet átvételi elismervénye 3000 db Szabó Dezső ex librisről, valamint az Egyetemi Nyomda számlája ugyancsak 3000 db ex librisről („Szabó Dezső könyvtárából”). - A Collegium még 1947 decemberében kapott 9000 db-ot (41. lj), amelyeket egyböl be is ragasztottak a könyvekbe. Ezúton is köszönöm Keresztes Csabának, a Nemzeti Levéltár munkatársának segítségét!

50 4231/1949. MT rendelet. 


\section{MARKÓ, VERONIKA}

\section{La première et la dernière bibliothèque de Dezső Szabó}

Tout au long de sa vie, l'écrivain Dezső Szabó (1879-1945) a passionnément collectionné les livres. Entre 1900 et 1904, il était étudiant du Collège Eötvös József, fondé sur l'exemple de l'École normale supérieure de Paris. Lors de ses passages en France, il acquit une quantité très importante de livres. Les lettres et les autres sources conservées aux archives du Collège Eötvös révèlent qu'en 1914 sa première collection de livres a été saisie è cause des dettes qu'il avait accumulées. Ne pouvant pas récupérer ses livres, il a demandé en 1916 au directeur du Collège - Géza Bartoniek - de racheter la collection, qui est conservée depuis dans la Bibliothèque Eötvös de l'Institut littéraire de l'Académie hongroise des Sciences. En 1947, une partie importante de la dernière collection de l'écrivain (mort lors du siège de Budapest), composée de quelque 6000 volumes, a également été transportée à la Bibliotheque Eötvös, grâce aux efforts de Dezső Keresztury, alors ministre de la culture et directeur du Collège.

Keywords: bookcollector, privat library, written heritage, Szabó Dezső, Eötvös College 